\title{
THE ROYAL COLLEGE OF PSYCHIATRISTS
}

EDUCATION COMMITTEE

\section{READING LISTS \\ IN PSYCHIATRY - 1981}

This new series of specialized Reading Lists gives a much wider coverage of the most notable work as seen by experts in their particular fields.

Part I Mental Handicap, Forensic Psychiatry, Social and Community Psychiatry, Psychiatry of Old Age. Pp 9. 35p.

Part II Addictions, Child and Adolescent Psychiatry. Pp 10.35p.

Part III Psychotherapy (in preparation)

Part IV General Reading List. Pp $41+$ contents list. $£ 1.00$

This list is compiled by Dr. J. Birtchnell and Dr. E. Gordon in a novel way using many subsections which include not only well-established psychiatric divisions such as 'affective disorders', 'behaviour therapy', 'disorders in childhood but also 'specifically female issues', 'employment', 'attitudes to the body and face', 'the interface between psychiatry and religion' and many more. Specially important references are printed in rather darker type. References also appearing in the specialist reading lists (above) are marked with an asterisk.

\section{Prices include postage and packing Order from HEADLEY BROTHERS LTD, Ashford, Kent TN24 8HH}

Printed in Great Britain by Headley Brothers Ltd The Invicte Press Ashford Kent and London 